\title{
Biometric and Chemical Characterization of Fruits From Selections of Platonia insignis Mart., Native of the State of Maranhão, Brazil
}

\author{
R. F. Santos ${ }^{1}$, J. R. G. Araujo ${ }^{1}$, A. C. V. Neves Junior ${ }^{1}$, P. A. F. R. Melo ${ }^{1}$, L. P. V. Silva ${ }^{1}$, W. F. S. Santos ${ }^{1}$, \\ B. M. M. Mendes ${ }^{1}$, A. E. Rocha ${ }^{1}$, M. B. Furtado ${ }^{2}$ \& M. L. R. Mesquita ${ }^{1}$ \\ ${ }^{1}$ Center of Agricultural Sciences, State University of Maranhão, São Luís, MA, Brazil \\ ${ }^{2}$ Center of Agricultural and Environmental Sciences, Federal University of Maranhão, Chapadinha, MA, Brazil \\ Correspondence: J. R. G. Araujo, Postgraduate Program in Agroecology, Center of Agricultural Sciences, State \\ University of Maranhão, Cidade Universitária Paulo VI, 1.000, 65.055-098, São Luís, MA, Brazil. Tel: \\ 55-98-987-250-992. E-mail: gusmaoaraujo50@gmail.com
}

Received: September 23, 2018

Accepted: November 22, 2018

Online Published: January 15, 2019

doi:10.5539/jas.v11n2p376

URL: https://doi.org/10.5539/jas.v11n2p376

\begin{abstract}
Brazil has a range of fruit species, especially native ones, which play an important role in the life of local populations, but are still little studied, as is the case of bacuri (Platonia insignis Mart.). P. insignis is a fruit tree species native from Amazon region and has great economic potential, mainly due to its excellent organoleptic and nutritional characteristics. Therefore, there is a need for research that seeks the proper use of the species, as well as the selection of superior genotypes. Thus, the objective of this study was to characterize biometric and chemically fruits of eight selections of native P. insignis plants, from the municipalities of Presidente Juscelino and Santa Rita both located in Lower Munim region, state of Maranhão, Brazil. For the biometric characterization, 20 fruits, individually, were analyzed as to mass, longitudinal diameter, transverse diameter, conformation index, seed number, parthenocarpic segments number, pulp yield and bark mass, and for the chemical characterization, samples composed of six fruits were analyzed as to soluble solids ( ${ }^{\circ}$ Brix), total acidity (\% citric acid), soluble solids/acidity ratio and $\mathrm{pH}$. There was significant difference for all characteristics evaluated. High coefficients of variation were observed, indicating variability among the selections and possibility of taking advantage for the genetic improvement. The results allow to indicate the fruits analyzed, both for the industrial market and for the in natura consumption, especially for the 'Domingão' and 'Mamão' selections.
\end{abstract}

Keywords: native species, diversity, fruit biometry, pulp quality

\section{Introduction}

Brazil is the third largest fruit producer in the world, with a planted area of approximately 2.8 million hectares and a production of 40,953 million tons per year (Anuário Brasileiro de Fruticultura, 2015).

Among the fruit species, the native ones are precious source of wealth for Brazil, that owns one of the main centers of genetic diversity of native fruit trees, for the most part, little studied. The native fruit species occupy a prominent place among the diverse ecosystems and, in general, they produce abundant, nutritious and succulent fruits, playing an important role in the nutrition of the local populations (Avidos \& Ferreira, 2003; Nogueira, 2009). In the north and northeast parts of the country one should highlight a monotypic species of the Clusiaceae family: the "bacurizeiro" (Platonia insignis Mart.).

P. insignis is a tree species native to the Amazon, with probable center of origin in the state of Pará, but it is also found in the states of Tocantins, Goiás, Mato Grosso, Piauí and Maranhão (Costa Junior, 2011; Moraes \& Gutjahr, 2011), which have this species as the fruit with the highest natural occurrence (Araujo et al., 2007).

In the state of Maranhão, P. insignis can be found in the regions of Pre-Amazônia, Western Lowlands, North Coast, Lençois Maranhenses/Munim, Center-South Savannah, Southern Extremity and Lower Parnaíba (Nascimento et al., 2007; Souza, 2011). According to the agricultural census of 2017 (IBGE, 2018), the state of Maranhão is the second in Brazil that contributes most to the production of $P$. insgnis fruits.

Fruits of $P$. insignis have great economic potential, mainly due to its excellent organoleptic and nutritional characteristics, which justify the wide market acceptance both for in natura consumption and for 
industrialization in the form of pulps, sweets, ice creams, juices, creams, among others, providing sustenance, employment and income for many families (Rufino et al., 2008).

It is worth mentioning that despite the wide utilitarian potential, as well as its socioeconomic importance for the populations surrounding native $P$. insignis plantations, it is a species still in the stage of domestication, and there are not sufficient management techniques that support the rational cultivation of this species, in addition, little is known about the particularities of the fruits in their naturally occurring environments.

The fruits of native $P$. insignis species do not have uniformity in vegetative and reproductive aspects, thus they must be studied in order to establish selection criteria (Borges et al., 2010). Santos et al. (2017) studying native $P$ insignis in the state of Maranhão observed significant genetic differences between populations. Souza et al. (2001) in a characterization study of native $P$. insignis fruits reported $13.79 \%, 14.36$ and 12.49 of pulp yield, soluble solids and acidity/sugars ratio, respectively, for fruits from the state of Maranhão.

Studies of characterization of superior mother plants, searching for fruits with high pulp yield and physical and chemical characteristics acceptable to the standards demanded by the market, are of paramount importance.

Therefore, the objective of this work was to perform the biometric and chemical characterization of fruits of native $P$. insignis selections of the Lower Munim Region, state of Maranhão.

\section{Material and Methods}

The research activities were carried out in the municipalities of Presidente Juscelino $\left(02^{\circ} 55^{\prime} 40^{\prime \prime} \mathrm{S}\right.$ and $44^{\circ} 03^{\prime} 54^{\prime \prime}$ W) and Santa Rita $\left(03^{\circ} 08^{\prime} 37^{\prime \prime} \mathrm{S}\right.$ and $\left.44^{\circ} 19^{\prime} 33^{\prime \prime} \mathrm{W}\right)$, both located in the state of Maranhão, in the Rosario microregion, Munim river hydrographic basin. The climate is described as humid B1, according to Thornthwaite classification, the average annual temperature is $27^{\circ} \mathrm{C}$, with annual rainfall totals varying from 1600 to 2000 $\mathrm{mm}$ and average annual relative humidity of $80 \%$. The vegetation is classified as savannah restinga, transition zone, and the soil is classified as Quartzarenic Neosol (Nugeo, 2018).

The fruits were obtained from eight selections of $P$. insignis, identified according to the names of the rural communities of occurrence or of the "owners" ('Boa Vista', 'Domingão' and 'Prata' from the municipality of Presidente Juscelino and 'Launé', 'Juninho', 'Sororoca', 'Mamão' and 'Marcos', from the municipality of Santa Rita, state of Maranhão, Brazil). According to historical reports of the local residents, the P. insignis plants had an estimated average age of $49.37 \pm 7.57$ years and mean height of $31.88 \pm 2.17 \mathrm{~m}$, which was obtained by the superposition of equal angles method (Silva; Neto, 1979). The individuals vegetated in their natural environment and received no cultural practices.

After the fruits have fallen naturally they were collected in January and February of 2017, with initial sampling of 20 fruits by $P$. insignis selection, which were properly packed and taken to the Plant Science and Post-Harvest Laboratory of the Maranhão State University to carry out the biometric and chemical analyses.

From the initial sample of 20 fruits, 12 were taken at random for the individual biometric characterization, by measuring the longitudinal (LD) and transverse (TD) diameters (mm), fruit (FM) (g) and bark masses (BM) (g) and counting of seed numbers (SN) and parthenocarpic segment number (PSN). Pulp yield (\% PY) was obtained by the relationship between the pulp mass and the fruit mass, and the conformation index (CI), by the relation between the longitudinal and transverse diameter. For this last ratio, an adaptation of the methodology described by Guimarães et al. (1992) was used, thus round fruits were those with CI between 1.00 and 1.20, and those with CI $>1.21$ were oval.

The fruit chemical analysis was carried out from two samples, each composed of the maceration of six fruits.

The total soluble solids (TSS) were determined by direct refractometer reading, in a digital refractometer, expressed directly in ${ }^{\circ}$ Brix and the hydrogen ionic potential $(\mathrm{pH})$ was determined by the potentiometer method in digital $\mathrm{pH}$ device, calibrating the potentiometer through the buffer solutions ( $\mathrm{pH} 4.0$ and 7.0), according to the methodology recommended by the Association of Official Analytical Chemistry (AOAC) (1992). Titratable total acidity (TTA) (\% citric acid) was obtained by titrating with a standard solution of $0.1 \mathrm{~N}$ sodium hydroxide and the chemical ratio (TSS/TTA), determined by the ratio of total soluble solids and titratable total acidity, according to AOAC (1992).

The experiment was laid out in a randomized complete design with eight treatments, and 12 replications for the biometric analyses and six replications for the chemical analyses. The data were subjected to Analyses of Variance with F test and the means were compared by the Scott-Knott test at 5\% probability. The correlations between the parameters studied (48 observations) were estimated by the Pearson correlation coefficient. Statistical analyses were performed by the InfoStat program version 2017.1.2.0. 


\section{Results and Discussion}

According to the statistical analysis of the fruit biometric characteristics, the selections differed significantly for fruit mass, which ranged from $266.48 \pm 23.20$ to $379.18 \pm 18.68 \mathrm{~g}$. According to Chitarra and Chitarra (2005), for the market of fresh fruits, in general, the heavier and larger fruits are more attractive to consumers, although characteristics such as external appearance, color, firmness, aroma and flavor also are considered. Thus, the 'Sororoca', 'Domingão', 'Juninho' and 'Mamão' P. insignis selections deserve special mention, with averages of $379.18 \pm 18.68,376.50 \pm 30.85,372.58 \pm 20.84$ and $335.42 \pm 19.89 \mathrm{~g}$, respectively (Table 1 ). However, in the case of P. insignis, this characteristic should be viewed carefully, since other characteristics may better indicate the fruit quality.

The results for this study, with an average mass of $330.57 \pm 15.31 \mathrm{~g}$, were higher than those found by Silva et al. (2009), who reported an average of $263 \mathrm{~g}$ for P. insignis fruits studied in the state of Maranhão, but lower than the results obtained by Neto; Carvalho (2004), with an average mass exceeding $349 \mathrm{~g}$, in a study with in the state of Pará. It is worth to note that Souza et al. (2001), in a study with P. insignis mother plants in general verified that fruits of the mother plants collected in the state of Piauí had average mass values higher than the fruits collected in the state of Maranhão.

The average variation of the longitudinal diameter (LD) of the P. Insignis selections was $82.19 \pm 1.79$ to 115 . $21 \pm 2.73 \mathrm{~mm}$, with notoriety for 'Mamão' $(115.51 \pm 2.73 \mathrm{~mm})$, 'Sororoca' $(113.13 \pm 2.49 \mathrm{~mm})$ and 'Marcos' $(110.98 \pm 2), 38 \mathrm{~mm}$ ). The transverse diameter (TD) ranged from $76.86 \pm 1.69$ to $88.11 \pm 1.70 \mathrm{~mm}$. The higher values were observed for 'Juninho' $(88.11 \pm 1.70 \mathrm{~mm})$ and 'Domingão' $(86.92 \pm 2.13 \mathrm{~mm})$, as shown in Table 1 .

Table 1. Total fruit mass (FM), longitudinal diameter (LD), transversal diameter (TD), conformation index (CI) and fruit shape from P. insignis selections native of the state of Maranhão, Brazil

\begin{tabular}{|c|c|c|c|c|c|}
\hline Selection & FM (g) & LD (mm) & TD (mm) & CI (LD/TD) & FORM \\
\hline Boa-Vista & $282.50 \pm 16.07 \mathrm{c}$ & $102.83 \pm 2.17 \mathrm{~b}$ & $76.86 \pm 1.69 \mathrm{c}$ & $1.34 \pm 0.02 \mathrm{a}$ & OVAL \\
\hline Domingão & $376.50 \pm 30.85 \mathrm{a}$ & $103.16 \pm 2.87 \mathrm{~b}$ & $86.92 \pm 2.13 \mathrm{a}$ & $1.19 \pm 0.03 \mathrm{~b}$ & ROUND \\
\hline Launé & $313.33 \pm 11.68 \mathrm{~b}$ & $92.86 \pm 2.10 \mathrm{c}$ & $82.21 \pm 1.40 \mathrm{~b}$ & $1.13 \pm 0.03 \mathrm{~b}$ & ROUND \\
\hline Juninho & $372.58 \pm 20.84 \mathrm{a}$ & $99.91 \pm 2.05 \mathrm{~b}$ & $88.11 \pm 1.70 \mathrm{a}$ & $1.13 \pm 0.01 \mathrm{~b}$ & ROUND \\
\hline Sororoca & $379.18 \pm 18.68 \mathrm{a}$ & $113.13 \pm 2.49 \mathrm{a}$ & $83.75 \pm 1.68 \mathrm{~b}$ & $1.35 \pm 0.02 \mathrm{a}$ & OVAL \\
\hline Mamão & $335.42 \pm 19.89 \mathrm{a}$ & $115.51 \pm 2.73 \mathrm{a}$ & $82.79 \pm 1.53 b$ & $1.40 \pm 0.04 \mathrm{a}$ & OVAL \\
\hline Marcos & $318.59 \pm 21.04 \mathrm{~b}$ & $110.98 \pm 2.38 \mathrm{a}$ & $78.43 \pm 2.10 \mathrm{c}$ & $1.42 \pm 0.02 \mathrm{a}$ & OVAL \\
\hline Prata & $266.48 \pm 23.20 \mathrm{c}$ & $82.19 \pm 1.97 \mathrm{~d}$ & $79.68 \pm 2.24 \mathrm{c}$ & $1.03 \pm 0.01 \mathrm{c}$ & ROUND \\
\hline Mean & 330.57 & 102.57 & 82.34 & 1.25 & \\
\hline P-value & 0.0006 & $<0.0001$ & 0.0002 & $<0.0001$ & \\
\hline CV (\%) & 22.17 & 8.15 & 7.65 & 6.54 & \\
\hline
\end{tabular}

Note. Data refer to means and mean standard error. $\mathrm{CV} \%=$ Coefficient of variation. Means followed by the same letter in the column do not differ by the Scott-Knott test at 5\% probability.

Teixeira (2000), and Aguiar (2008), respectively, found variations from 70 to $150 \mathrm{~mm}$ and from 61 to $128 \mathrm{~mm}$, for fruit longitudinal diameter, and from 67 to $70 \mathrm{~mm}$ and 57 to $95 \mathrm{~mm}$, for fruit transversal diameter. Souza et al. (2001), in their studies in thet states of Piauí and Maranhão, reported similar results, evidencing that the results of this study agree with the literature.

With regards to the conformation index (CI), round fruits are favored by the industry for facilitating the cleaning and processing operations (Chitarra and Chitarra, 2005). Thus, the selections 'Prata' (1.03 mm), 'Juninho' (1.13 $\mathrm{mm})$, 'Launé' $(1.13 \mathrm{~mm})$ and 'Domingão' $(1.19 \mathrm{~mm})$, stood out and were classified as round fruits. The selections 'Boa-Vista' $(1.34 \mathrm{~mm})$, 'Sororoca' $(1.35 \mathrm{~mm})$, 'Mamão' $(1.40 \mathrm{~mm})$ and 'Marcos' $(1.42 \mathrm{~mm})$ were classified as oval fruits (Table 1). Guimarães et al. (1992) reported a variation between 0.86 and $1.30 \mathrm{~mm}$, for this parameter indicating that the variation in fruit format in this study was expressive.

The number of seeds/fruit (SN) varied in average from 1.58 to 2.92 units/fruit. Carvalho et al. (2003) found an average of 2.30 seeds/fruit, and Souza et al. (2001) reported an average of 2.44 seeds/fruit, corroborating the results of this study (Table 2). The selections of 'Launé', 'Domingão' and 'Boa Vista' with values of 2.92 \pm 0.29 , $2.67 \pm 0.33$ and $2.50 \pm 0.29$ seeds/fruit, respectively, had higher average values for this variable, therefore, a higher number of seeds per fruit. Thus, these selections have potential for the seminal propagation of $P$. insignis, since 
this species is mostly propagated by seeds, even when the grafting is aimed at. According to Mourão (1992), it is worth noting the utility of $P$. insignis seeds which are not useful for human consumption, but bran, a byproduct of the seed processing can be used in animal feed and as fertilizer. According to Souza et al. (2000), P. insignis lard, obtained from seeds, is widely used in the treatment of several dermatosis and can also be used as raw material in the soap industry. However, from a commercial point of view, fruits with less seeds are sought, since pulp is still the main product of interest. Considering this, we highlight the Silver (1.58 \pm 0.19$)$ and Mark $(1.92 \pm 0.26)$ selections, which presented the smallest means for SN.

The high coefficient of variation (CV\%) of $40.36 \%$, observed for SN, indicates high dispersion of the data. This is attributed to the fact that some fruits have one, while others, four seeds, evidencing the inefficiency in the $P$. insignis pollination systems.

The pulp yield (PY\%) provides subsidies for agroindustry use (Carvalho et al., 2003). Moreover, it values fruit extractivism. With regards to pulp yield, the selections 'Marcos', 'Mamão', 'Prata' and 'Domingão' were statistically superior to the other selections, with averages of $19.98 \pm 0.76,18.33 \pm 1.65,18.05 \pm 0.81$ and $17.07 \pm 1.43 \%$, respectively. In general, larger fruits had higher pulp yield, as in the case of the 'Mamão' and 'Domingão' selections, however, it is worth to note the 'Prata' selection, which, although with lower mass, showed higher pulp yield than fruits of larger mass, such as those from the 'Sororoca' and 'Juninho' selections.

The values obtained in this study were higher than those found by Silva et al. (2010), in a study with $P$. insignis fruits from the state of Maranhão, with average pulp yield of $11.82 \%$, and similar to those reported by Aguiar et al. (2008), in a study with P. insignis fruits from the state of Piauí, which varied from 11.69 to $22.21 \%$ (Table 2).

Table 2. Seed number (SN), parthenocarpic segment number (PSN), bark mass (BM) and pulp yield (PY) from native $P$. insignis fruit selections from the state of Maranhão, Brazil

\begin{tabular}{lllll}
\hline Selection & SN & PSN & BM (g) & PY (\%) \\
\hline Boa-Vista & $2.50 \pm 0.29 \mathrm{a}$ & $2.08 \pm 0.19 \mathrm{~b}$ & $197.50 \pm 13,19 \mathrm{~b}$ & $14.20 \pm 0.90 \mathrm{~b}$ \\
Domingão & $2.67 \pm 0.33 \mathrm{a}$ & $2.25 \pm 0.30 \mathrm{~b}$ & $246.50 \pm 26,41 \mathrm{a}$ & $17.07 \pm 1.43 \mathrm{a}$ \\
Launé & $2.92 \pm 0.29 \mathrm{a}$ & $1.75 \pm 0.22 \mathrm{~b}$ & $199.58 \pm 8.04 \mathrm{~b}$ & $15.58 \pm 1.52 \mathrm{~b}$ \\
Juninho & $2.17 \pm 0.27 \mathrm{~b}$ & $2.08 \pm 0.26 \mathrm{~b}$ & $258.33 \pm 12.48 \mathrm{a}$ & $14.12 \pm 0.96 \mathrm{~b}$ \\
Sororoca & $2.25 \pm 0.25 \mathrm{~b}$ & $2.42 \pm 0.19 \mathrm{~b}$ & $262.50 \pm 17.13 \mathrm{a}$ & $16.06 \pm 1.76 \mathrm{~b}$ \\
Mamão & $2.08 \pm 0.19 \mathrm{~b}$ & $2.58 \pm 0.15 \mathrm{a}$ & $218.33 \pm 13.85 \mathrm{a}$ & $18.33 \pm 1.65 \mathrm{a}$ \\
Marcos & $1.92 \pm 0.26 \mathrm{~b}$ & $2.83 \pm 0.24 \mathrm{a}$ & $196.93 \pm 11.94 \mathrm{~b}$ & $19.98 \pm 0.76 \mathrm{a}$ \\
Prata & $1.58 \pm 0.19 \mathrm{~b}$ & $3.33 \pm 0.22 \mathrm{a}$ & $181.16 \pm 15.50 \mathrm{~b}$ & $18.05 \pm 0.81 \mathrm{a}$ \\
\hline Mean & 2.26 & 2.42 & 220.10 & 16.67 \\
P- value & 0.0190 & 0.0002 & 0.0011 & 0.0276 \\
CV (\%) & 40.36 & 32.56 & 25.15 & 27.67 \\
\hline
\end{tabular}

Note. Data refer to means and mean standard error. CV\% $=$ Coefficient of variation. Means followed by the same letter in the column do not differ by the Scott-Knott test at $5 \%$ probability.

According to Lima et al. (2002), fruits with pulp yield superior to $50 \%$ have suitable conditions for commercialization, which implies considering the fruits studied with low pulp yield. However, according to Carvalho and Muller (2005), the low P. insignis pulp yield percentage does not constitute a characteristic that prevents the use of a certain fruit, either as fresh fruit or for industrial use.

With regards to the parthenocarpic segment number (PSN), their presence in the fruit in large quantities is highly desired for both in natura and industrial use, since they are not adhered to the seeds and are easy to remove. In the above-mentioned study, the averages ranged from $1.75 \pm 0.22$ to $3.33 \pm 0.22 \mathrm{PSN} /$ fruit, with emphasis on the 'Prata', 'Marcos', and 'Mamão' selections, with averages of 3.33 $\pm 0.22,2.83 \pm 0.24$ and 2.58 \pm 0.15 PSN/fruit, respectively. Similar results were found by Souza et al. (2001) who found reported a variation in the PSN from 2.50 to 3.14 and by Silva et al. (2009) who found an average of 2.45 PSN/fruit.

For the characteristic bark mass (MC), the averages ranged from $181.16 \pm 15.50$ to $262.50 \pm 17.13 \mathrm{~g}$, with highlight for the 'Sororoca', 'Juninho', 'Domingão' and 'Mamão' selections, which differed statistically from the others, with averages of $262.50 \pm 17.13,258.33 \pm 12.48,246.50 \pm 26.41$ and $218.33 \pm 13.85 \mathrm{~g}$, respectively (Table 2). 
When the fruit destination is in natura consumption, the pulp yield and the parthenocarpic segment number is the most important characteristic, since the seeds and bark will be discarded. However, the $P$. insignis fruit bark presents economic importance, because it is possible to use it for the preparation of sweets, ice creams and creams, which can greatly increase fruit yield (Souza et al., 1996). The importance of using the largest fraction of P. insignis fruit is adding value and nutritional positive aspects. In addition, peels are rich in fiber and pectin, which are compounds known to be beneficial to the human body, therefore they should be considered as excellent raw materials from the food point of view (Matietto et al., 2006).

The results for total soluble solids (TSS) presented a mean of $16.30 \pm 0.58$ and $19.47 \pm 0.06{ }^{\circ} \mathrm{Brix}$ (Table 2). These values are higher than those found by Silva et al. (2010) who verified an interval of 13.27 to $14.83{ }^{\circ} \mathrm{Brix}$, and also to those reported by Fontenele et al. (2010), who found a mean value of $14^{\circ}$ Brix in a P. Insignis pulp study.

The total soluble solids content is a parameter that has been used as an indicator of the quality of fruits intended for industrialization, since they are closely related to higher yields during processing, thus, there is a preference for fruits with higher soluble solids contents at $13{ }^{\circ}$ Brix (Maniwara et al., 2014). Therefore, the 'Mamão' and 'Launé' selections, with averages of $19.47 \pm 0.06$ and $18.63 \pm 0.18{ }^{\circ}$ Brix, respectively, differed statistically from the others.

Titratable acidity is an important parameter in the assessment of the state of conservation of a food product and is very important, especially at high levels, as regards processing, because they are better preserved and provide conditions that make difficult the deterioration by micro-organisms (Magro et al., 2006). The total titratable acidity (TTA) ranged from $0.48 \pm 0.01$ to $1.33 \pm 0.03 \%$ of citric acid. The highest percentage was observed in fruits of the 'Marcos' selection, which differed significantly from the others. Souza et al. (2001) and Carvalho et al. (2003) in research carried out with $P$. insignis showed citric acid values in the range of 0.62 to $2.02 \%$ and 1.13 to $1.34 \%$, respectively, indicating that the fruits analyzed by these authors had higher acidity than those from this study. This qualify the fruits from this research for the consumption in natura, particularly those from the 'Boa-Vista' selection, which presented lower acidity (0.48\%) (Table 3).

Table 3. Total soluble solids (TSS), total tritatable acidity (TTA), chemical ratio (TSS/TTA) and hydrogenionic potential $(\mathrm{pH})$ of fruits from $P$. insignis native from the state of Maranhão, Brazil

\begin{tabular}{lllll}
\hline Selection & TSS $\left({ }^{\mathbf{0}}\right.$ Brix) & TTA $(\%$ citric acid) & RATIO (TSS/TTA) & pH \\
\hline Boa-Vista & $16.30 \pm 0.24 \mathrm{c}$ & $0.48 \pm 0.01 \mathrm{~d}$ & $34.24 \pm 0.86 \mathrm{a}$ & $3.95 \pm 0.02 \mathrm{~b}$ \\
Domingão & $17.87 \pm 0.12 \mathrm{~b}$ & $0.75 \pm 0.07 \mathrm{c}$ & $25.11 \pm 2.60 \mathrm{~b}$ & $3.71 \pm 0.07 \mathrm{c}$ \\
Launé & $18.63 \pm 0.18 \mathrm{a}$ & $0.70 \pm 0.08 \mathrm{c}$ & $28.72 \pm 3.24 \mathrm{~b}$ & $3.98 \pm 0.12 \mathrm{~b}$ \\
Juninho & $17.60 \pm 0.25 \mathrm{~b}$ & $0.73 \pm 0.06 \mathrm{c}$ & $25.14 \pm 2.05 \mathrm{~b}$ & $4.14 \pm 0.10 \mathrm{a}$ \\
Sororoca & $17.70 \pm 0.12 \mathrm{~b}$ & $0.74 \pm 0.03 \mathrm{c}$ & $24.09 \pm 0.97 \mathrm{~b}$ & $4.06 \pm 0.04 \mathrm{a}$ \\
Mamão & $19.47 \pm 0.06 \mathrm{a}$ & $0.72 \pm 0.08 \mathrm{c}$ & $28.66 \pm 2.87 \mathrm{~b}$ & $3.87 \pm 0.03 \mathrm{~b}$ \\
Marcos & $16.71 \pm 0.58 \mathrm{c}$ & $1.33 \pm 0.03 \mathrm{a}$ & $12.60 \pm 0.69 \mathrm{c}$ & $3.47 \pm 0.02 \mathrm{~d}$ \\
Prata & $17.07 \pm 0.54 \mathrm{c}$ & $1.00 \pm 0.03 \mathrm{~b}$ & $16.99 \pm 0.33 \mathrm{c}$ & $3.78 \pm 0.04 \mathrm{c}$ \\
Mean & 17.67 & 0.81 & 24.44 & 3.87 \\
P-value & $<0.0001$ & $<0.0001$ & $<0.0001$ & $<0.0001$ \\
CV (\%) & 3.83 & 17.21 & 20.94 & 3.84 \\
\hline
\end{tabular}

Note. Data refer to means and mean standard error. $\mathrm{CV} \%=$ Coefficient of variation. Means followed by the same letter in the column do not differ by the Scott-Knott test at 5\% probability.

The chemical TSS/TTA ratio ranged from $12.60 \pm 0.69$ to $34.24 \pm 0.86$ (Table 3). Souza et al. (2001) and Aguiar et al. (2008), in their studies with $P$. insignis, obtained averages for the TSS/TTA ratio, in the range of 4.94 to 26.11 and 5.00 to 35.00 , respectively, which are close to those found in this study. The TSS/TTA ratio is an important indication of taste, since it relates sugars to fruit acids, being more representative than the isolated measurement of these components (Fachinello \& Nachtigal, 2018), determining, by taste balance, the general quality of a product. Thus, the 'Boa-Vista' selection, which showed an average of $34.24 \pm 0.86$, deserves special mention.

As with acidity, the determination of the hydrogen ionic potential $(\mathrm{pH})$ provides valuable data in the appreciation of the state of conservation of a food product (Rufini et al., 2011). Regarding this characteristic, the averages varied from $3.47 \pm 0.03$ to $4.14 \pm 0.10$, with superiority for the 'Juninho' and 'Sororoca selections', which showed averages of $4.14 \pm 0.10$ and $4.06 \pm 0.04$, respectively, characterizing them as low acid fruits (Table 3). The results 
are within the limits commonly reported in the literature, such as Silva et al. (2010), with variation from 3.22 to 3.48, Bezerra et al. (2004), with an average of 3.12 and Fontenele et al. (2010), with an average of 3.19.

The correlation analyses for the assessed characteristics allows to evaluate the magnitude and the direction of the influences of one variable on the other, giving an indicative of association between the characteristics analyzed (Sousa et al., 2007).

The Pearson correlation analyses between the studied variables, expressed in Table 4, found a positive and significant relationship between the fruit mass (FM) and the number of parthenocarpic segments (PSN) ( $\mathrm{r}=$ $0.36)$, number of seeds $(\mathrm{r}=0.53)$, pulp yield $(\% \mathrm{PY})(\mathrm{r}=0.32)$, longitudinal diameter $(\mathrm{LD})(\mathrm{r}=0.59)$, and transverse diameter (TD) $(r=0.92)$, showing that the higher the value of any of these variables, implies a larger fruit mass, as expected. Positive correlations indicate that the two characteristics are benefited or impaired by the same causes of variation.

It is important to highlight the significant correlations observed between PSN and SN $(\mathrm{r}=-0.75)$ and $\%$ PY $(\mathrm{r}=$ 0.28), which show that the lower SN, the higher the PSN and the higher the \% PY. Similar results were obtained by Silva et al. (2009), in research with $P$. insignis fruits. Thus, for the prospection of good selections of $P$. insignis, special attention should be given to the PSN, since it directly affects the the main attribute in P. insignis fruits: the pulp yield.

The conformation index (CI) obtained by the relation LD/TD, presented a high and significant correlation with $\mathrm{LD}(\mathrm{r}=0.82)$. Thus, the greater the LD, the more distant from the value 1 , where the more rounded fruits are considered, the more oval tends to be the fruit. The correlation between CI and TD was lower $(r=-0.44)$, which, in turn, showed a significant correlation with the PSN $(r=0.39), \mathrm{SN}(\mathrm{r}=0.55)$ and LD $(\mathrm{r}=0.42)$ parameters (Table 4).

With regards to the chemical characteristics of the $P$. insignis fruits, it was observed that the correlations between $\mathrm{pH} \times$ TTA $(\mathrm{r}=-0.78), \mathrm{pH} \times \mathrm{TSS}(\mathrm{r}=0.12), \mathrm{TSS} \times \mathrm{TTA}(\mathrm{r}=-0.16)$ and TSS $\times$ RATIO $(\mathrm{r}=0.22)$ were not significant (Table 4), but the correlation between $\mathrm{pH} \times$ RATIO $(\mathrm{r}=0.72)$ was significant and positive, indicating that the higher the $\mathrm{pH}$, the higher the RATIO, and the correlation between RATIO and TTA $(\mathrm{r}=-0.96)$, was significant and negative suggesting that the lower the acid content the higher the RATIO (Table 4).

Table 4. Pearson correlation among the variables fruit mass (FM), conformation index (CI), parthenocarpic segment number (PSN), seed number (SN), pulp yield (PY), longitudinal diameter (LD), transversal diameter (TD), total titratable acidity (TTA), total soluble solids (TSS) and ratio TSS/TTA, from P. insignis fruit selections native of the state of Maranhão, Brazil

\begin{tabular}{|c|c|c|c|c|c|c|c|c|c|c|}
\hline & FM & CI & PSN & SN & PY & LD & TD & TTA & TSS & TSS/TTA \\
\hline CI & 0.07 & & & & & & & & & \\
\hline PSN & $0.36^{* *}$ & 0.11 & & & & & & & & \\
\hline SN & $0.53 * *$ & 0.16 & $-0.75 * *$ & & & & & & & \\
\hline PY & $0.32 *$ & -0.22 & $0.28 *$ & -0.16 & & & & & & \\
\hline LD & $0.59 * *$ & $0.82 * *$ & -0.09 & 0.15 & 0.07 & & & & & \\
\hline TD & $0.92 *$ & $-0.44 * *$ & $0.39 * *$ & $0.55 * *$ & 0.11 & $0.42 * *$ & & & & \\
\hline TTA & -0.12 & 0.07 & 0.11 & -0.12 & 0.26 & 0.01 & -0.13 & & & \\
\hline TSS & 0.08 & 0.03 & -0.11 & 0.06 & 0.11 & 0.09 & 0.15 & -0.16 & & \\
\hline TSS/TTA & 0.10 & 0.01 & -0.17 & 0.15 & -0.17 & 0.04 & 0.08 & $-0.96 * *$ & 0.22 & \\
\hline $\mathrm{pH}$ & 0.18 & -0.24 & -0.04 & 0.03 & -0.12 & -0.09 & 0.25 & -0.78 & 0.12 & $0.72 * *$ \\
\hline
\end{tabular}

Note. $^{* *}$ : significant at $1 \%$ probability; $*$ : significant at $5 \%$ probability.

Large variations were observed among the selections studied, judging by the coefficient of variation (CV\%) estimates with values that ranged from $3.83 \%$, for total soluble solids to $40.36 \%$, for seed number. This variation can be attributed to uncontrolled environmental components, such as soil, climate, age of the plant selections or even the origin of the $P$. insignis, that could be from different mother plants. It is also considered that part of this variation is attributed to the selections, being, therefore, of genetic character. Santos et al. (2017), studying $P$. insignis from an extractive reserve located in the state of Maranhão, verified high genetic diversity within the studied populations (two groups composed of 15 individuals). 
Considering that $P$. insignis is a fruit in process of domestication, these variations are common, according to Morzelle et al. (2015). Thus, biometric and chemical characterization are valuable tools to detect variability within populations of the same species, implying the possibility of selection of promising materials for the formation of germplasm, besides being an efficient way of improving fruit quality intended for both the fresh fruit market and industrial processing.

\section{Conclusions}

(1). There was high variability for the analyzed characteristics, particularly for biometric, such as fruit mass, seed number, parthenocarpic segments number and pulp yield.

(2). The variability for the parameters demonstrates the presence of different genotypes in the population with potential characteristics for the breeding of the species.

(3). The selections present potential for both in natura consumption and industrial processing. For the in natura consumption, we highlight the selections 'Domingão' and 'Mamão', considering the results for parthenocarpic segment number, pulp yield, total soluble solids and sugar/acid ratio. As for the industrial potential, the selections 'Domingão', 'Mamão' and 'Launé', considering the results for pulp yield and total soluble solids.

(4). The parthenocarpic segment number, seed number and pulp yield are directly related to fruit mass, as well as the parthenocarpic segment number with pulp yield.

\section{References}

Aguiar, L. P., Figueiredo, R. W., Alves, R. L., Maia, G. A., \& Souza, V. A. B. (2008). Caracterização física e físico-química de frutos de diferentes genótipos de bacurizeiro (Platonia insignis Mart.). Ciências e Tecnologia de Alimentos, 28(2), 423-428. https://doi.org/10.1590/S0101-20612008000200024

Anuário Brasileiro de Fruticultura. (2015). In R. R. Beling (Ed.), Anuário Brasileiro de Fruticultura 2017 (p. 88 ). Santa Cruz do Sul: Editora Gazeta.

AOAC (Association of Official Analytical Chemistry). (1992). Official methods of Analysis of the Association of Official Analytical Chemistry (15th ed.). Washington.

Araujo, J. R. G., Carvalho, J. E. U., \& Martins, M. R. (2007). Porta-enxertos para o bacurizeiro: Situação e Perspectivas. In M. da C. Lima (Ed.), Bacuri: Agrobiodiversidade (1st ed., pp. 47-63). São Luís: Instituto Interamericano de Cooperação para a Agricultura.

Avidos, M. F. D., \& Ferreira, L. T. (2003). Frutos dos cerrados: Preservação gera muitos frutos. Revista Biotecnologia Ciência \& Desenvolvimento, 3(15), 36-41.

Bezerra, G. A. S., Maia, G. A., Filgueira, R. W., Gomes, A. M. M., \& Souza Filho, M. S. M. (2004). Influência da redução da atividade de água, adição de conservantes e branqueamento na preservação da polpa de bacuri por métodos combinados. Boletim Centro de Pesquisa de Processamento de Alimentos, 22(2), 217-232. https://doi.org/10.5380/cep.v22i2.1191

Borges, K. C. F., Santana, D. G., Melo, D., \& Santos, C. M. (2010). Rendimento de polpa e morfometria de frutos e sementes de pitangueira-do-cerrado. Revista Brasileira de Fruticultura, 32(2), 471-478. https://doi.org/ $10.1590 / \mathrm{S} 0100-29452010005000042$

Carvalho, J. E. U., \& Muller, C. H. (2005). Caracterização fisica de frutos de matrizes selecionadas de bacurizeiro (p. 379). Congresso Brasileiro de Fruticultura, 19, 2005, Cabo Frio. Anais... Cabo Frio: UENP/UFRURAL.

Carvalho, J. E. U., Nazaré, R. F. R., \& Nascimento, W. M. O. (2003). Características físicas e físico-químicas de um tipo de bacuri (Platonia insignis Mart.) com rendimento industrial superior. Revista Brasileira de Fruticultura, 25(2), 326-328. https://doi.org/10.1590/S0100-29452003000200036

Chitarra, A. B., \& Chitarra, M. I. F. (2005). Pós-colheita de frutos e hortaliças: Fisiologia e manuseio (p. 783). Lavras: UFLA.

Costa Junior, J. S. (2011). Análise Fitoquímica e Toxicológica das Sementes de Platonia insignis Mart (Bacuri) (p. 217, Tese (Doutorado em Genética e Toxicologia Aplicada), Universidade Luterana do Brasil, Canoas).

Fachinello, J. C., \& Nachtigal, J. C. (2018). Colheita e armazenamento. In J. C. Nachtigal, J. C. Fachinello, \& E. Kersten (Eds.), Fruticultura: fundamentos e prática. Pelotas: Embrapa Clima Temperado, Livro Eletrônico. 
Fontenele, M. A., Figueiredo, R. W., Maia, G. A., Alves, R. E., Sousa, P. H. M., \& Souza, V. A. B. (2010). Conservação pós-colheita de bacuri (Platonia insignis Mart.) sob refrigeração e embalado em PVC. Revista Ceres, 57(3), 292-296. https://doi.org/10.1590/S0034-737X2010000300002

Guimarães, A. D. G., Mota, M. G. C., \& Nazaré, R. F. R. (1992). Coleta de germoplasma de bacuri (Platonia insignis Mart.) na Amazônia (p. 25). I: microrregião Campos de Marajó (Soure/Salvaterra). Belém: Embrapa-CPATU.

IBGE (Instituto Brasileiro de Geografia e Estatística). (2018). Censo agropecuário 2017.

Lima, E. D. P. A., Lima, C. A. A., Aldrigue, M. L., \& Gondim, P. J. S. (2002). Caracterização física e química dos frutos da umbucajazeira (Spondias spp.) em cinco estádios de maturação da polpa congelada e néctar. Revista Brasileira de Fruticultura, 24(2), 338-343. https://doi.org/10.1590/S0100-29452002000200013

Magro, N. G. D., Coelho, S. R. M., Haida, K. S., Berté, S. D., \& Moraes, S. S. (2006). Comparação físico-química de frutos congelados de Butiá Eriospatha (Mart.) Becc. do Paraná e Santa Catarina, Brasil. Revista Varia Scientia, 6(11), 33.

Maniwara, P., Nakano, K., Boonyakiat, D., Ohashi, S., Hiroi, M., \& Tohyama, T. (2014). The use of visible and near infrared spectroscopy for evaluating passion fruit postharvest quality. Journal of Food Engineering, 143(2), 33-43. https://doi.org/10.1016/j.jfoodeng.2014.06.028

Mattietto, R. A., Souza, M. G. S., \& Yano, C. Y. B. (2006). Tecnologia para Obtenção de Doce da Casca do Bacuri. Belém Embrapa-CPATU (Comunicado Técnico, 175).

Moraes, L. R. B., \& Gutjahr, E. (2011). Química de Oleogenosas-Valorização da Biodiversidade Amazônica (p. 83). Editora GIZ.

Morzelle, M. C., Bachiega, P. S. E. C., Boas, E. V. B. V., \& Lamounier, M. L. (2015). Caracterização química e física de frutos de curriola, gabiroba e murici provenientes do cerrado brasileiro. Revista Brasileira de Fruticultura, 37(1), 96-103. https://doi.org/10.1590/0100-2945-036/14

Mourão, K. S. M. (1992). Morfologia e desenvolvimento de frutos, semente e plântulas de Platonia insignis Mart. (Clusiaceae) (p. 90, Dissertação (Mestrado em Biologia Vegetal), Universidade Estadual Paulista, Rio Claro).

Nascimento, W. M. O., Carvalho, J. E. U., \& Müller, C. H. (2007). Ocorrência e distribuição geográfica do bacurizeiro. Revista Brasileira de Fruticultura, 29(3), 657-660. https://doi.org/10.1590/S0100-2945200 7000300044

Neto, J. T. F., \& Carvalho, J. E. U. (2004). Estimativas de correlação e repetibilidade para caracteres do fruto de bacurizeiro. Ciência e Agrotecnologia, 28(4), 300-305. https://doi.org/10.1590/S1413-70542004000200008

Nogueira, D. H. (2009). Qualidade e potencial de utilização de frutos de genótipos de carnaubeira (Copernicia prunifera) oriundos do estado do Ceará (111f., (Tese (Doutorado em Agronomia), Universidade Federal da Paraíba, Paraíba).

Nugeo. (2018). Atlas do Maranhão (p. 42). São Luís, MA: Laboratório de Geoprocessamento/GEPLAN-UEMA.

Rufini, J. C. M., Galvão, E. R., Prezotti, L., Silva, M. B., \& Parrella, R. A. C. (2014). Caracterização biométrica e físico-química dos frutos de acessos de manga 'Ubá'. Revista Brasileia de Fruticultura, 33(2), 456-464. https://doi.org/10.1590/S0100-29452011005000061

Rufino, M. S. M. (2008). Propriedades funcionais de frutas tropicais brasileiras não tradicionais (p. 263, Tese (Doutorado em Agronomia), Universidade Federal Rural do Semiárido).

Santos, E. M., Monteiro Neto, C. A. S., Nascimento, C. A. J., Muniz, F. H., \& Barros, J. R. S. (2017). Genetic and population diversity of bacuri (Platonia insignis Mart.) in Chapada Limpa extractive reserve, Maranhão State, Brazil. African Journal of Biotechnology, 16(50), 2317-2325. https://doi.org/10.5897/AJB2017.16254

Silva, J. A. A., \& Neto, F. P. (1979). Princípios básicos de dendrometria (p. 191). Recife: Departamento de Ciência Florestal, Universidade Federal Rural de Pernambuco.

Silva, R. G., Chaves, M. C. L., Arnhold, E., \& Cruz, C. D. (2009). Repetibilidade e correlações fenotípicas de caracteres do fruto de bacuri no Estado do Maranhão. Acta Scientiarum. Agronomy, 31(4), 587-591. https://doi.org/10.4025/actasciagron.v31i4.723 
Silva, V. K., Figueiredo, R. W., Brito, E. S., Maia, G. A., Sousa, P. H. M., \& Figueiredo, E. A. T. (2010). Estabilidade da polpa do bacuri (Platonia insignis Mart.) congelada por 12 meses. 1293. Ciência e Agrotecnologia, 34(5), 1293-1300. https://doi.org/10.1590/S1413-70542010000500030

Sousa, C. S., Silva, S. A., Hansen, D. S., \& Fonseca, A. A. O. (2007). Correlações entre caracteres físicos e químicos de jenipapeiros nativos do Recôncavo Baiano. Revista Brasileira de Biociências, 5(2), $270-272$.

Souza, A. G. C., Sousa, N. R., Silva, S. E. L., Nunes, C. D. M., Canto, A. C., \& Cruz, L. A. A. (1996). Fruteiras da Amazônia (p. 40). Brasília, DF: Embrapa-SP.

Souza, I. G. B. (2011). Caracterização morfológica e molecular do bacurizeiro (Platonia insignis Mart.) (107f., Tese (Mestrado em Genética e Melhoramento), Universidade Federal do Piauí, Brazil).

Souza, V. A. B., Araújo, E. C. E., Vasconcelos, L. F. L., \& Alves, R. E. (2000). Bacurizeiro (Platonia insignis Mart.) (p. 72). Jaboticabal: Funep.

Souza, V. A. B., Araújo, E. C. E., Vasconcelos, L. F. L., \& Lima, P. S. C. (2003). Variabilidade de características físicas e químicas de frutos de germoplasma de bacuri da Região Meio-Norte do Brasil. Revista Brasileira de Fruticultura, 23(3), 677-683. https://doi.org/10.1590/S0100-29452001000300047

Teixeira, G. H. A. (2000). Frutos do bacurizeiro (Platonia insignis Mart): Caracterização, qualidade e conservação (p. 106, Dissertação (Mestrado em Agronomia), Faculdade de Ciências Agrárias e Veterinárias, Universidade Estadual Paulista, Brazil).

\section{Copyrights}

Copyright for this article is retained by the author(s), with first publication rights granted to the journal.

This is an open-access article distributed under the terms and conditions of the Creative Commons Attribution license (http://creativecommons.org/licenses/by/4.0/). 